DOI https://doi.org/10.18551/rjoas.2017-09.26

\title{
EMPIRICAL ANALYSIS COMPANY SIZE, CORPORATE GOVERNANCE AND AUDIT QUALITY TO EARNING MANAGEMENT IN INDONESIA
}

\author{
Mawardi Rizal \\ Faculty of Economics and Bussiness, Airlangga University, Indonesia \\ E-mail: rizal.mawardi@gmail.com
}

\begin{abstract}
In the preparation of accrual basis accounting financial statements are selected because it can reflect the company's financial condition directly. Policymakers provide flexibility for management to be able to choose the accounting standards applied to the company. Management takes advantage of the freedom of selection of certain accounting policies in order to provide good earnings reporting in the financial statements. This study aims to analyze the effect of firm size and good corporate governance (GCG) to earnings management with moderation variables that is audit quality. This research is a quantitative research using secondary data. The sample selection was done by purposive sampling method and the data processing method using hypothesis analysis and multigroup analysis. The data used is obtained from Indonesia Stock Exchange and processed by using Smart PLS. The results showed that firm size variables did not significantly influence positively to earnings management but the variable of Good Corporate Governance (GCG) had a significant positive effect on earnings management. Audit quality can not moderate the effect of firm size on earnings management. The researchers hope that the results of this study will provide new insights for academics and practitioners regarding the relationship between Corporate Size, Good Corporate Governance (GCG) and Audit Quality to Profit Management.
\end{abstract}

\section{KEY WORDS}

Company, size, corporate governance, profit, management.

Profit is the company's main goal in undergoing operations that take place in each period. Practically operational, earnings can be seen in the financial statements of each company, according to (Agustia, 2013). The financial statements are one of the important things for some external parties as well as internal parties. In the financial statements contain a collection of information concerning the financial position, performance, change of a company's financial position, and beneficial to economic decision-making. Profit information is a major concern for assessing performance or management presentations.

In the preparation of financial statements, accrual-based accounting is chosen because it can reflect the company's financial condition directly. In general, management will take advantage of the freedom of selection of certain accounting policies in order to provide good earnings reporting in the financial statements. This allows management to perform accounting practices with profit-oriented numbers that will result in low quality reported earnings resulting in errors in decision making (Barus \& Setiawati, 2015).

According Sunandar et. al., (2014) states the actions of managers will impact on the quality of earnings that will result in lower financial statements. The low quality of this information served by the management is due to the practice of earnings management as the impact of agency problems. Accounting practices undertaken by management that also impacts the size of the company in the eyes of the parties shareholders and ownership of the company.

Researchers are interested to examine whether firm size is influential in implementing earnings management practices and researchers are interested in examining whether good corporate governance (GCG) affects earnings management practices Where the use of audit quality variables as moderating variables is based on the role of the auditor as an independent party in giving opinion on reports Finance. 
Research Questions. Based on the background of the research described earlier, then in this study formulated problems in the research questions as follows:

- Does corporate size have a significant effect on earnings management?

- Does Good Corporate Governance (GCG) significantly affect earnings management?

- Does corporate size have a significant effect on earnings management with audit quality as a moderating variable?

- Does Good Corporate Governance (GCG) significantly affect earnings management with audit quality as a moderating variable?

Research Purpose. From the above explanation, the purpose of this research is to know:

- The effect of Company Size on Profit Management;

- The influence of Good Corporate Governance (GCG) on earnings management;

- The effect of firm size on earnings management with audit quality as a moderating variable;

- The influence of Good Corporate Governance (GCG) on earnings management with audit quality as a moderating variable.

\section{LITERATURE REVIEW AND HYPOTHESIS}

Theoretical Framework:

Agency Theory. Agency Theory in Sari Kartika Rini et al. (2013), is the basic theory in running the company's business practices so far. The main principle of this theory states the existence of a working relationship between the authorizer (prisipal) ie the investor with the party who receives the authority (agent) ie manager, in the form of work contract.

The shareholder is the principal who forms the contract to maximize his or her wellbeing with ever-increasing profitability. The agency problem arises because of the opportunistic nature of the agent that is the management behavior to maximize its own wellbeing by contradicting the pricipal interests. Managers have a strong impetus to choose and apply accounting methods that can show good market reactions that are merely aimed at getting a prestigious bonus (Rahadi and Asyik Fadjrih Nur 2014).

Earning Management. Earnings management is a fraud committed by the management on the financial statements presented deliberately overstate profits or lower profits with the aim of getting a bonus clean. According to Alvin Arens et al. (2011: 372), states "the case of fraud in the financial statements involves an attempt to overstate income whether by overstatement of assets and revenues or by removing liabilities and expenses, companies also deliberately reducing the present profits." Fraudulent financial statements are aimed at exaggerating or degrading net income even though this is not entirely wrong in managing earnings management.

So, earning management is the effect of some motivations. Motivation according to Bismark et al. (2015), to conduct earnings management that is: a) Meet the target within the company. Fully targets will affect the quality of the company; b) Attract the sympathy of investors who have invested or who want to invest their capital into the company; c) Establish or smooth out earnings; d) 'Good Looking' the financial statements to make it easier to get loans from banks or loans from other parties.

Firm Size. Rowland et al (2015), states the size of a company can be measured by total assets. The measurement is often used to identify the size of a company because the greater the assets owned by the company, the higher the capital invested. The larger the size of the company, the more valid the information available to investors in decision-making in relation to investment investment in the company's stock is more and more.

Company size is the grouping of companies into several groups, among large, medium and small enterprises. According Kodriyah (2015). Large companies will be more concerned with the community so they will be more careful in doing financial reporting, so that the impact of the company reported the condition more accurately. The larger the company and the extent of the business, will result in the owner can not manage his own company directly. 
Therefore the emergence of agency problems. Large companies tend to take less profit management measures than small firms. Due to the big companies often get stronger pressure in presenting the financial statements.

Corporate Governance. Corporate Governance is one way of entity policy to restore investor confidence in order to strengthen legislation and policies to reduce potential fraud in the entity (Wagimin 2015: 50). According to Hery (2016: 252) corporate governance is highly relied upon for internal auditors to handle the development and maintain the effectiveness of internal control systems, ensure the implementation of risk management, and ensure the creation of the possibility and failure in the organization.

According to Tunggal Widjaja Amin (2016: 44-48) said the importance of the accountant's role is significantly involved in the implementation activities of the principles of Good Corporate Governance (GCG), namely fairness, accountability, transparency, responsibility.

Quality Audit. Audit quality can be seen from running the profession. Auditors are required to be independent in detecting possible irregularities or fraud behaviors committed by the management in preparing financial statements according to the results of research (Doan and Erwin 2013).

According to Wiryadi Arri and Sebrina Nurzi (2013) quality is defined a word that is used universally and has become a determinant in business success. While the audit is a systematic process by ensuring the information that has been presented in the financial statements of the company's operational activities are truly objective, reliable, and reliable. The conclusions of the process are presented in the form of audit reports communicated to stakeholders. Therefore, the audit quality of an auditor plays an important role to assess the professional's results of a person's auditor in handling or detecting the client's financial statements.

Hypothesis Development:

Company Size to Earning Management. According to Doan and Erwin (2013) that company size affects earnings management. The existence of the description that large companies that have a lot of assets that will be more likely to dare to use capital from loans (debt financing) in buying all assets, whether fixed assets or current assets that can be used to expand the business, compared with small size companies.

However, inversely proportional to the research Lestiyana Fita (2014) that the size of the company has no effect on earnings management by the management.

H1: The size of the firm significantly affects earnings management.

Good Corporate Governance to Earning Management. The concept of good corporate governance, it can be concluded that a good application will generate shareholder rights to obtain information about the company's overall internal conditions and management obligations to disclose all information related to the company so as to reduce the practice of earnings management by the company (Kadek, 2014 ).

According to the research of Rahadi Pricilia Hana (2013) the mechanism of good corporate governance includes the size of the board of directors and the size of the board of commissioners to earnings management that the size of the board of directors affect the earnings management and the size of the board of commissioners does not affect earnings management.

H2: Good corporate governance significantly affects earnings management.

Company Size to Profit Management with Audit Quality As Moderation Variables. According to research (Sari, 2014) KAP big four or non big four can minimize earnings management practices, the management manipulates earnings to increase company size and avoid costs incurred by the company. Manipulation tends to be done by small and large companies in order to have a good performance performance.

According to research (Marjani and Endah, 2013) say firm size has a significant influence in handling earnings management practices.

H3: Audit quality is able to moderate the effect of firm size on earnings management.

Good Corporate Governance to Profit Management With Audit Quality As Moderation Variable. According to Sari et al (2013) study the practice of earnings management has a 
significant impact on Good Corporate Governance (GCG) although with audit quality as a moderating variable. Profit can be seen in the financial statements, the resulting profits must be qualified in order to increase investor confidence. Trust that is the benchmark how good the company in minimizing earnings management practices. Audit quality should be supported by the implementation of GCG value in the hope of supporting the company in reducing earnings management practices. Good earnings quality is proven after the audit by public accounting firm big four and non big four. Thus the investors are more interested and believe to invest their shares into the company. Good quality must go hand in hand with the application of GCG to the company, to ensure equality of information owned by investors and management.

H4: Audit quality is able to moderate the influence of Good Corporate Governance (GCG) on earnings management.

\section{Dependent Variable:}

Earning Management. In this study, the dependent variable used is earnings management proxied by discretionary accrual. Research literature by Hana (2014) states that earnings management has been modified based on research conducted by Dechow et al. (1995) the change of accounts receivable can be included in the model assuming that all credit sales are due to the practice of earnings management, because it is more easily engineered Compared to cash. This modified Jones model can be believed to have a better impact than other models. To measure the discretionary accruals, first calculate the total accrual for each firm $i$ in year $t$ with the Jones modification method that is:

$$
\text { DACCit }=\text { TACCit/Ait }- \text { NDACCit }
$$

To search for Total Accruals (TACC) the following models are used:

$$
\text { TACCit }=\text { Niit }- \text { CFOit }
$$

Where: TACCit $=$ Total accruals; Niit $=$ Net Income; CFOit $=$ Cash Flow Operation . follows:

The total accrual value (TACC) is estimated using the OLS regression equation as

$$
\text { TACCit } / \text { Ait-1 }=\beta 1(1 / \text { Ait-1 })+\beta 2(\Delta \text { Revt/Ait-1 })+\beta 3(P P E t / A i t-1)+e
$$

By using the above regression coefficient, the non discretionary accrual (NDACC) value can be calculated by the formula:

$$
N D A C C i t=\beta 1(1 / \text { Ait-1 })+\beta 2(\Delta R e v t / \text { Ait-1- } \Delta \text { Rect/Ait-1 })+\beta 3(P P E t / A i t-1)
$$

Where: DACCit $=$ discretionary Accruals of firm $\mathrm{i}$ in period $\mathrm{t}$; NDACCit $=$ non Discretionary Accruals firm i in period $t$; TACCit $=$ total accruals of firm $i$ in period $t$; Niit $=$ company's net profit $\mathrm{i}$ in period $\mathrm{t}$; CFOit $=$ cash flows from company's operating activities $\mathrm{i}$ in period $\mathrm{t}$; Ait-1 = total assets of firm $\mathrm{i}$ in period $\mathrm{t}-1 ; \Delta$ Revt $=$ change of company earnings $\mathrm{i}$ in period $\mathrm{t}$; PPEt $=$ fixed assets of the company in period $\mathrm{t}$; $\Delta$ Rect $=$ change of receivables of company $\mathrm{i}$ in period $\mathrm{t} ; \beta=$ regression coefficient; $\mathrm{e}=$ errors.

\section{Independent Variables:}

Company Size (UP). Company size according to Kodriyah (2015) can affect the management of the company in the management of profit, because the greater the company the more information available to users of financial statements in decision making. Company size can be measured from the logarithm of total assets owned by the company..

Good Corporate Governance (PK). Sari et al. (2013), suggests that Good Corporate Governance (GCG) or governance is one of the key elements in improving economic 
efficiency, which includes a combination of corporate management, board of commissioners, shareholders and other stakeholders.

Ratio Independent CEO (UD). According to Agustia Dian (2013) the role of board of commissioners is to monitor the policies of directors who are expected to minimize agency issues that arise between the board of directors and shareholders. The number of independent commissioners shall represent at least $30 \%$ and the total number of commissioners in the board of commissioners (BAPEPAM -KL Regulation No. IX.I.5). The proportion of independent board of commissioners is calculated using the percentage of independent commissioners compared to the total number of commissioners.

Board Size (KA). According Hana (2014) states that the size of the board of directors is the number of members of the board of directors in the company. The existence of a board of directors is called to serve as the primary internal control mechanism to monitor the managers of the company, the size of the board of directors is measured using the indicator of the number of members of the board of directors of a company.

Moderation Variable (MA). Audit Quality An auditor plays an important role in assessing the outcome of one's auditor's personality in handling or detecting clients' financial statements (Wiryadi Arri and Sebrina Nurzi 2013).

According to Sudjatna Indiferent and Muid Dul (2015) audit quality can be categorized into 2 things ie companies that are audited by KAP Big 4 and non Big 4 companies. Audit quality is expressed in dummy variables based on external KAP used by the company. Code 1 is provided if the company uses the Big-four services to audit its company, and code 0 if the company uses Non Big 4 external audit services.

Data collection technique:

The population in this study used 101 companies listed on the Indonesia Stock Exchange (IDX) in the period 2014-2015 with the following criteria:

1. A manufacturing company issuing financial statements for the period 2014-2015.

2. Those companies whose shares are actively traded in the Indonesia Stock Exchange (BEI).

3. Complete company data is in Indonesia Stock Exchange (BEI).

4. Companies that publish financial statements and annual reports on the company website or BEI website during the period 2014-2015 and expressed in rupiah (Rp) so that the value is not affected by the fluctuation of the rupiah against the dollar.

Sampling technique used is to use purposive sampling that is a particular consideration technique (Sugiyono 2013: 392). Therefore, the number of samples from the entire population that has been determined criteria, this study using a sample of 101 manufacturing companies at the time period financial statements of 2014 to 2015. Data sources can be obtained from the Indonesian Capital Market Directory (ICMD).

\section{Research Model:}

Descriptive Statistics. Descriptive statistics are statistics that describe the phenomenon or characteristics of the data under study. These statistics provide frequency values, measurement of control tendencies, and measure of shapes (Jogiyanto, 2007: 166).

Moderated Regression Analysis (MRA). Imam Ghozali (2012: 229) Moderated Regression Analysis (MRA) is different from sub-group analysis, because it uses an analytic approach that maintains the integrity of the sample and provides a basis for controlling the influence of moderator variables. To use an MRA with one predictor variable $(X)$, then we have to compare three regression equations to determine the moderator variable type. The two equations are:

$$
\begin{gathered}
Y i=\alpha+\beta 1 X i+e \\
Y i=\alpha+\beta 1 X i+\beta 2 Z i+\beta 3 X i^{*} Z i+e
\end{gathered}
$$

If the equation (Equation Two) The variable $Z$ is the pure moderator variable, then the equations (First Equation) and (Second Equation) are different $(\beta 2=0 ; \beta 3 \neq 0)$. 
The regression equation model developed in this study based on Moderated Regression Analysis (MRA) is as follows:

$$
\begin{gathered}
M A=\alpha+\beta 1(U P)+e \\
M A=\alpha+\beta 1(G C G)+e \\
M A=\alpha+\beta 1(U P)^{*}(K A)+e \\
M A=\alpha+\beta 1(G C G)^{*}(K A)+e
\end{gathered}
$$

Where: MA - discretionary accruals; $\alpha$ - Constants; $\beta$ - The variable coefficients; UP Company Size; GCG - Proportion of board of commissioners and number of directors; e Error term.

Test Validity Model PLS. Konstuk validity is to show how well the results obtained from the use of a measurement fit the theories used to define a construct (Hartono, 2008a). Results Outer loadings (measurement model) or convergent validity are used to test the unidimensionality of each construct. The strong correlation between the construct and the question items and the weak relationship with other variables is one way to test the convergence validity and discriminant validity.

Test of PLS Model Reliability. In addition to the validity test, PLS also performs a reliability test to measure the internal consistency of the measuring instrument. Reliability demonstrated accuracy, consistency, and accuracy of a measuring instrument in measuring (Hartono, 2008a). Reliability test in PLS can use two methods, namely Cronbcach's alpha and Composite realibility.

Cronbach's alpha for measuring the reliability of a construct limit value with a minimum 0.6 and Composite realibility was rated better in estimating the internal konsistensu a construct should be greater than 0.7 according to the study (Salisbury, Chin, Gopal, and Newsted, 2002).

\section{RESULTS OF STUDY}

Descriptive Statistics. Company Size as measured by Total Assets, the average total assets for 202 companies in the Indonesia Stock Exchange 2014-2015 is Rp. $9,081,972,716,300.00$. While the standard deviation for total assets is Rp. 3.703.103.309.737,00. Companies that have the least total assets are PT. Semen Baturaja Persero Tbk. In the year 2014 of Rp. 29.263.600.000,00 while which has the largest total assets is PT. Champion Pasific Indonesia Tbk in 2015 amounting to Rp. 38.353.493.604.000,00.

From 202 companies in BEl during 2014-2015, it is observed that the variable of good corporate governance is firstly the average size of proportion of commissioners measured through independent commissioner divided by total commissioner of $38.36 \%$ with standard deviation of $13.876 \%$. While the second is the size of directors as measured by the number of directors owned by each company, with the average number of directors owned is 4.8713 or rounded to 5 people and whereas the standard deviation of 2.35278 or 2 people.

The sample of companies that have been taken and studied the average audit quality listed in Indonesia Stock Exchange is 33\% of companies audited partner / use the services of Public Accountant Firm (KAP) Big Four and the remaining 67\% of companies do not partner on / Not using the services of Big Four Public Accountant Firm (KAP) with standard deviation of $47.19 \%$.

It can be concluded that the results of this study show that earnings management is measured using discretionary accruals, with an average of 202 companies in Indonesia Stock Exchange 2014-2015 amounted to 73.90, with the lowest value of 0.00 and the highest of 10,876. In the research (Rahadi Pricilia Hana, 2014) that this can be in the indication of earnings management with the pattern of increasing income. 
Moderated Regression Analysis (MRA)

Table 1 - Path Coeffecient Konstata

\begin{tabular}{|c|c|c|c|c|c|c|c|c|c|c|c|}
\hline \multicolumn{4}{|c|}{ Sebelum di moderasi } & \multicolumn{4}{c|}{ KAP Big 4 } & \multicolumn{4}{c|}{ KAP Non Big 4 } \\
\hline- & GCG & MA & UP & - & GCG & MA & UP & - & GCG & MA & UP \\
\hline GCG & - & 0.214 & - & GCG & - & 0.070 & - & GCG & - & 0.112 & - \\
\hline MA & - & - & - & MA & - & - & - & MA & - & - & - \\
\hline UP & - & 0.203 & - & UP & - & 0.241 & - & UP & - & 0.351 & - \\
\hline
\end{tabular}

Source: Output Smart PLS 2.0.

Table 2 - Path Coeffecient Standar Error

\begin{tabular}{|c|c|c|c|}
\hline \multirow{2}{*}{-} & \multicolumn{3}{|c|}{ Standard Error (STERR) } \\
\cline { 2 - 4 } & Sebelum di moderasi & KAP Big 4 & KAP Non Big 4 \\
\hline GCG -> MA & 1.308542 & 0.081779 & 0.116536 \\
\hline UP -> MA & 0.984018 & 0.111521 & 0.143982 \\
\hline
\end{tabular}

Source: Output Smart PLS 2.0.

Based on the results of regression output above, to determine a variable is a moderation variable, the test results that have been described whether audit quality is a variable that can moderate the relationship between company size and good corporate governance to earnings management practices. Comparing the four equations is:

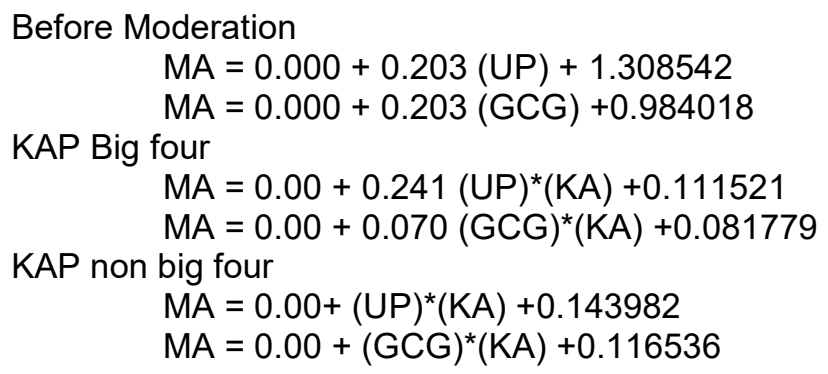

Model Measurement Test (Outer Model):

Validity tests. Figure 1 shows the value of outer loading in each variable above 0.5 in each variable so it can be said valid. While the regression coefficient is owned by the variable size of the company of 0.203 and good corporate governance of 0.214 .

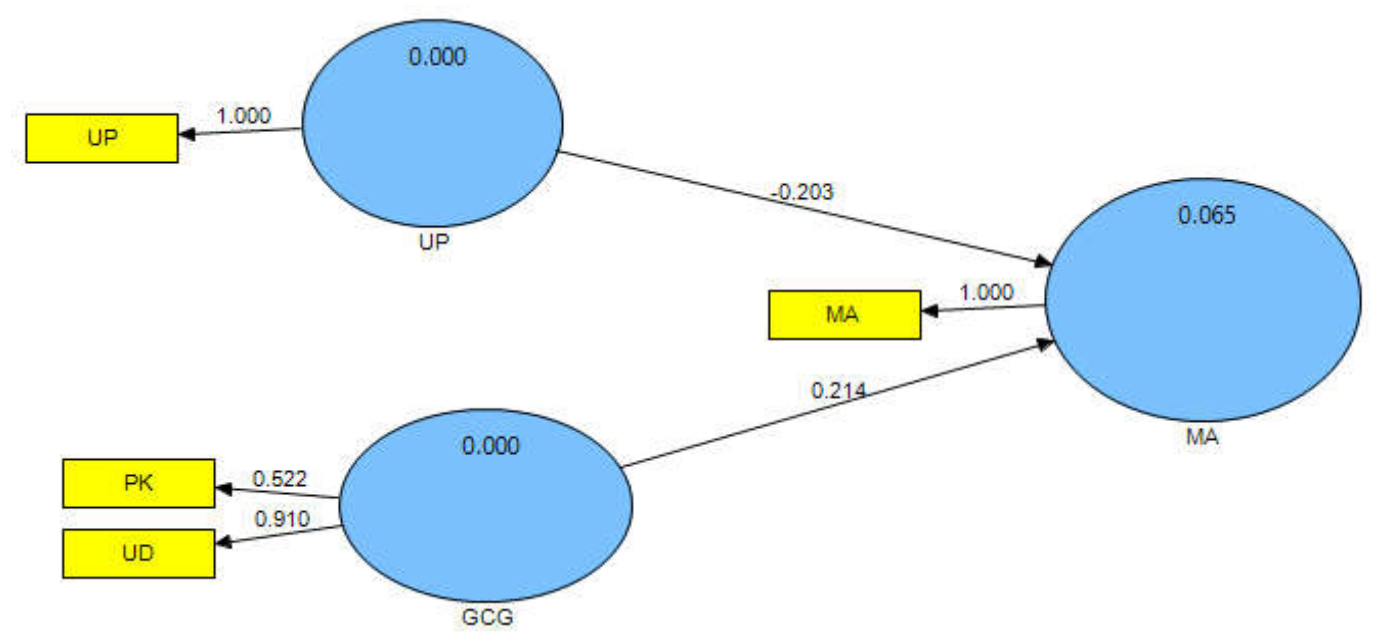

Figure 1 - Company Size and Good Corporate Governance (GCG) on Profit Management Source: Output Smart PLS 2.0 


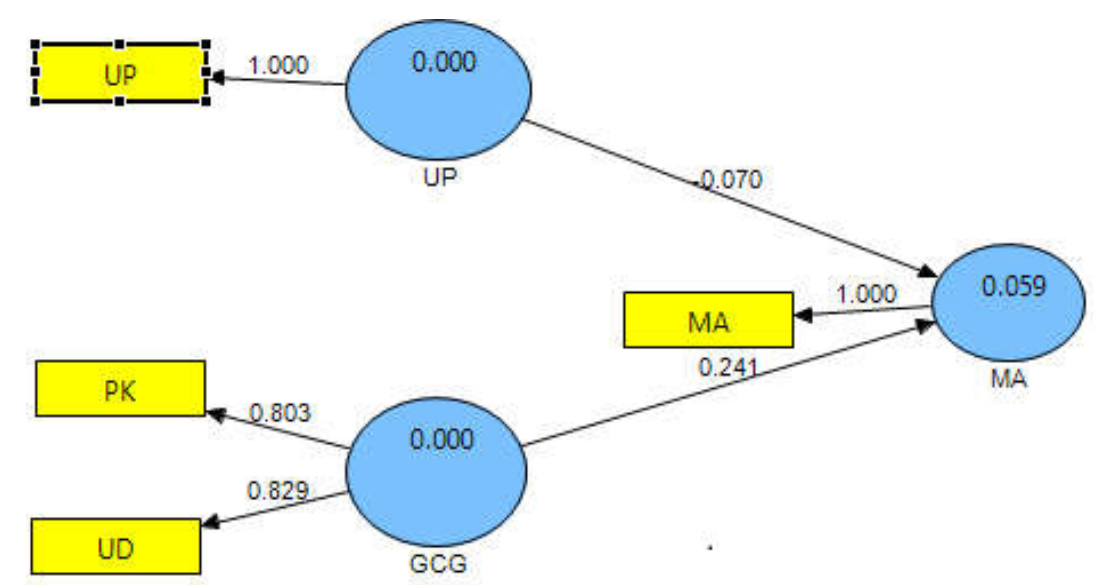

Figure 2 - Company Size and Good Corporate Governance (GCG) on Profit Management with moderate variables Audit Quality of Big-four Source: Output Smart PLS 2.0

Figure 2 shows the value of outer loading in each variable above 0.5 in each variable so it can be said valid. While the regression coefficient is owned by the variable size of the company of 0.070 and good corporate governance of 0.241 .

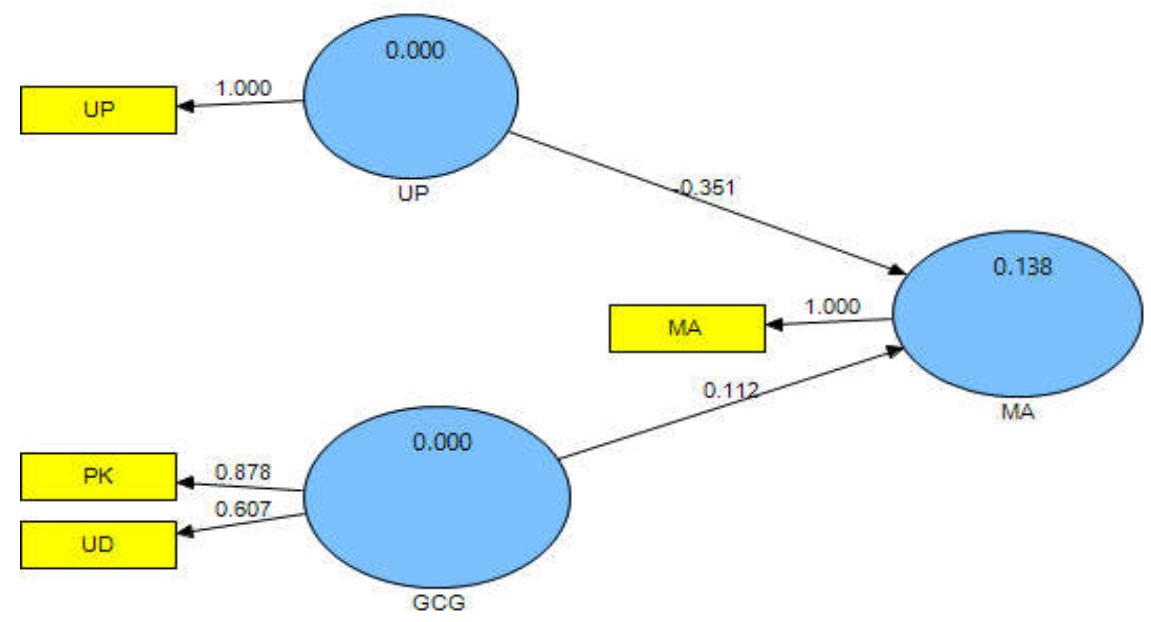

Figure 3 - Company Size and Good Corporate Governance (GCG) on Profit Management with moderate variables Quality Audit KAP-Non BigFour Source: Output Smart PLS 2.0

Figure 3 shows the value of outer loading in each variable above 0.5 in each variable so it can be said valid. While the regression coefficient is owned by the variable size of the company of 0.361 and good corporate governance of 0.112 .

Table 3 - Outer Loading

\begin{tabular}{|c|c|c|c|c|c|c|c|c|c|}
\hline \multicolumn{4}{|c|}{ Sebelum Moderasi } & \multicolumn{3}{c|}{ KAP BIG 4 } & \multicolumn{3}{c|}{ KAP NON BIG 4 } \\
\hline- & GCG & MA & UP & GCG & MA & UP & GCG & MA & UP \\
\hline MA & - & 1 & - & - & 1 & - & - & 1 & - \\
\hline PK & 0.522 & - & - & 0.803 & - & - & 0.878 & - & - \\
\hline UD & 0.910 & - & - & 0.829 & - & - & 0.607 & - & - \\
\hline UP & - & - & 1 & - & - & 1 & - & - & 1 \\
\hline
\end{tabular}

Source: Output Smart PLS 2.0

All indicators in the constructs in the study have the value of outer loading above 0.50 in table 4.3. This explains that all the indicators that exist in all constructs in this study meet the requirements of convergent validity. 
Table 4 - Average Variance Extraced dan Communality Value

\begin{tabular}{|c|c|c|c|c|c|c|}
\hline \multirow{2}{*}{-} & \multicolumn{2}{|c|}{ Before Moderating } & \multicolumn{2}{c|}{ KAP BIG 4 } & \multicolumn{2}{c|}{ KAP NON BIG 4 } \\
\cline { 2 - 7 } & AVE & Communality & AVE & Communality & AVE & Communality \\
\hline GCG & 0.55079 & 0.55079 & 0.50716 & 0.50716 & 0.5693 & 0.5693 \\
\hline MA & 1 & 1 & 1 & 1 & 1 & 1 \\
\hline UP & 1 & 1 & 1 & 1 & 1 & 1 \\
\hline
\end{tabular}

Source: Output Smart PLS 2.0

Meanwhile, the AVE and Communality values generated by all constructs in this study satisfy the convergence validity requirement of $>0.50$ which means to meet the requirements of convergent validity.

Table 5 - Cross Loading

\begin{tabular}{|c|c|c|c|}
\hline \multicolumn{4}{|c|}{ Before Moderating } \\
\hline- & GCG & MA & UP \\
\hline MA & 0.16242 & 1 & -0.1486 \\
\hline PK & 0.52243 & 0.07427 & -0.0077 \\
\hline UD & 0.9103 & 0.15298 & 0.29818 \\
\hline UP & 0.25296 & -0.1486 & 1 \\
\hline \multicolumn{4}{|c|}{ KAP BIG 4 } \\
\hline- & GCG & MA & UP \\
\hline MA & 0.19443 & 0.01357 & -0.0384 \\
\hline PK & 0.5381 & 0.19489 & 0.23151 \\
\hline UD & 0.99762 & -0.0384 & 0.25717 \\
\hline UP & 0.27133 & KAP NON BIG 4 & 1 \\
\hline \multicolumn{5}{|c|}{ MA } & UP \\
\hline MA & GCG & 1 & -0.3546 \\
\hline PK & 0.1226 & 0.11179 & -0.1589 \\
\hline UD & 0.8775 & 0.06747 & 0.19905 \\
\hline UP & 0.60712 & -0.3546 & 1 \\
\hline
\end{tabular}

Source: Output Smart PLS 2.0

In table 4.5 it can be seen that every variable before and after moderation qualify because cross loading above 0.50. Discriminant in this study meets the requirement of discriminant validity that is $>0.50$ which means to fulfill discriminant validity requirement.

Table 6 - Correlation of Latent Variable and Average Variance Extracted

\begin{tabular}{|c|c|c|c|c|c|c|}
\hline \multicolumn{7}{|c|}{ Before Moderating } \\
\hline- & GCG & MA & UP & & AVE & $\sqrt{\text { AVE }}$ \\
\hline GCG & 1 & - & & GCG & 0.55079 & 0.74215 \\
\hline MA & 0.16242 & 1 & & MA & 1 & 1 \\
\hline UP & 0.25296 & -0.1486 & 1 & UP & 1 & 1 \\
\hline \multicolumn{7}{|c|}{ KAP BIG 4} \\
\hline- & GCG & MA & UP & & AVE & VAVE \\
\hline GCG & 1 & & & GCG & 0.50716 & 0.71215 \\
\hline MA & 0.1226 & 1 & & MA & 1 & 1 \\
\hline UP & -0.0312 & -0.3546 & 1 & UP & 1 & 1 \\
\hline \multicolumn{7}{|c|}{ KAP NON BIG 4} \\
\hline - & $\overline{G C G}$ & $\mathrm{MA}$ & UP & & AVE & VAVE \\
\hline GCG & 1 & - & & GCG & 0.5693 & 0.75452 \\
\hline MA & 0.19443 & 1 & & MA & 1 & 1 \\
\hline UP & 0.27133 & -0.0384 & 1 & UP & 1 & 1 \\
\hline
\end{tabular}

Source: Output Smart PLS 2.0

Table 5 can be seen that the square root value of AVE is greater than the correlation value between the latent construct in the same column. This explains that all constructs in this research model meet the requirements of discriminant validity. 
Table 7 - Cronbcach's alpha dan Composite Realibility Value

\begin{tabular}{|c|c|c|c|c|c|c|c|c|}
\hline \multicolumn{3}{|c|}{ Before Moderating } & \multicolumn{4}{c|}{ BIG 4 } & \multicolumn{3}{c|}{ NON BIG 4 } \\
\hline- & $\begin{array}{c}\text { Cronbachs } \\
\text { Alpha }\end{array}$ & $\begin{array}{c}\text { Composite } \\
\text { Reliability }\end{array}$ & - & Cronbachs Alpha & $\begin{array}{c}\text { Composite } \\
\text { Reliability }\end{array}$ & - & $\begin{array}{c}\text { Cronbachs } \\
\text { Alpha }\end{array}$ & $\begin{array}{c}\text { Composite } \\
\text { Reliability }\end{array}$ \\
\hline GCG & 0.61842 & 0.69557 & GCG & 0.6 & 0.7 & GCG & 0.6 & 0.7 \\
\hline MA & 1 & 1 & MA & 1 & 1 & MA & 1 & 1 \\
\hline UP & 1 & 1 & UP & 1 & 1 & UP & 1 & 1 \\
\hline
\end{tabular}

Source: Output Smart PLS 2.0

The value of cronbachs alpha and composite reliability generated in this study is $>0.60$ so it can be said that all constructs can be said reliable. The result of reliability test in this research can be seen in table 7 .

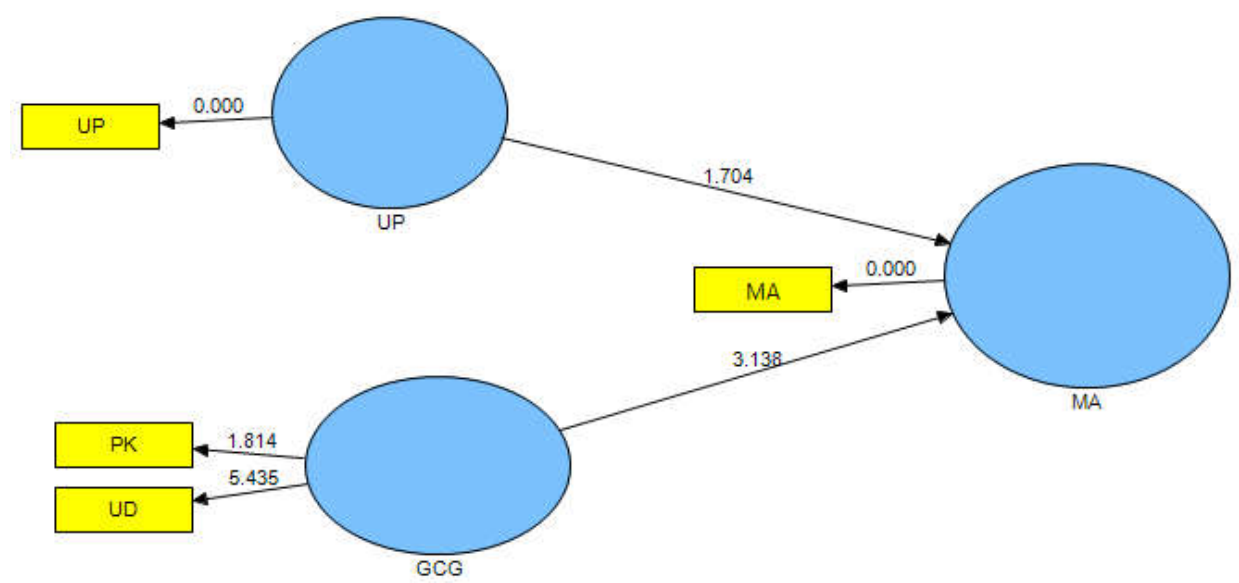

Figure 4 - Company Size and Good Corporate Governance (GCG) on Profit Management Source: Output Smart PLS 2.0

Figure 4 shows that company size has a value of 1.704 while the value of Good Corporate Governance (GCG) is 3.136, which indicates that firm size does not affect earnings management period 2014-2015.

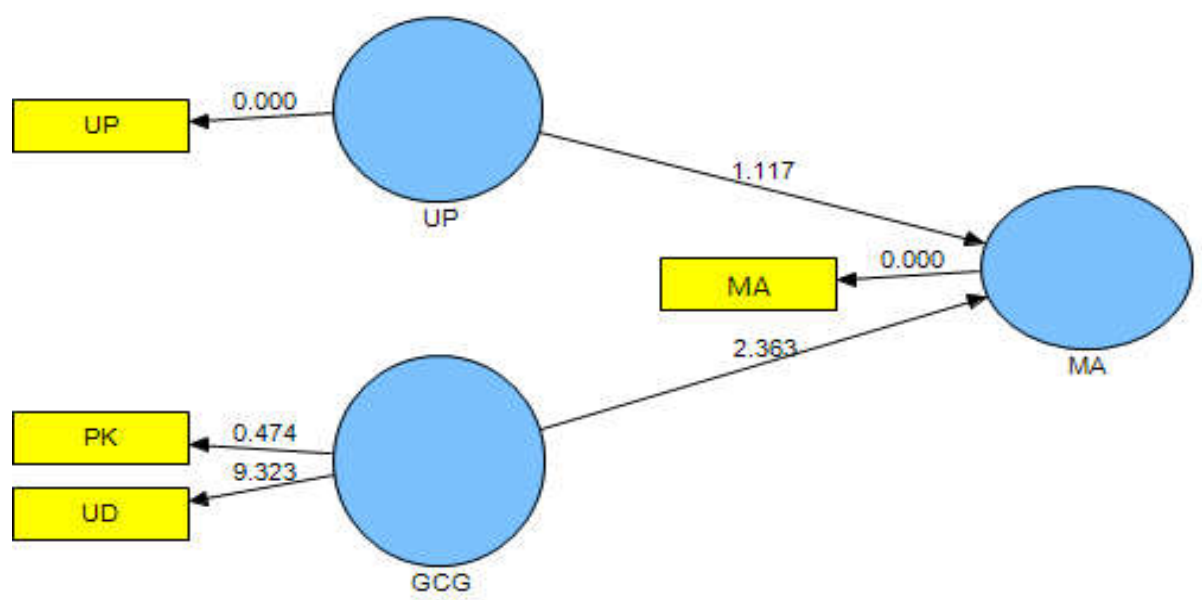

Figure 5 - Company Size and Good Corporate Governance (GCG) on Profit Management with moderate variables Audit Quality of BigFour Source: Output Smart PLS 2.0

Judging from the figure 4.6 that audit quality is audited by public accountant big four on company size variable with value 1,117 whereas value of variable of Good Corporate Governance (GCG) is 2,363 , indicating that firm size does not affect earnings management in period 2014-2015. 


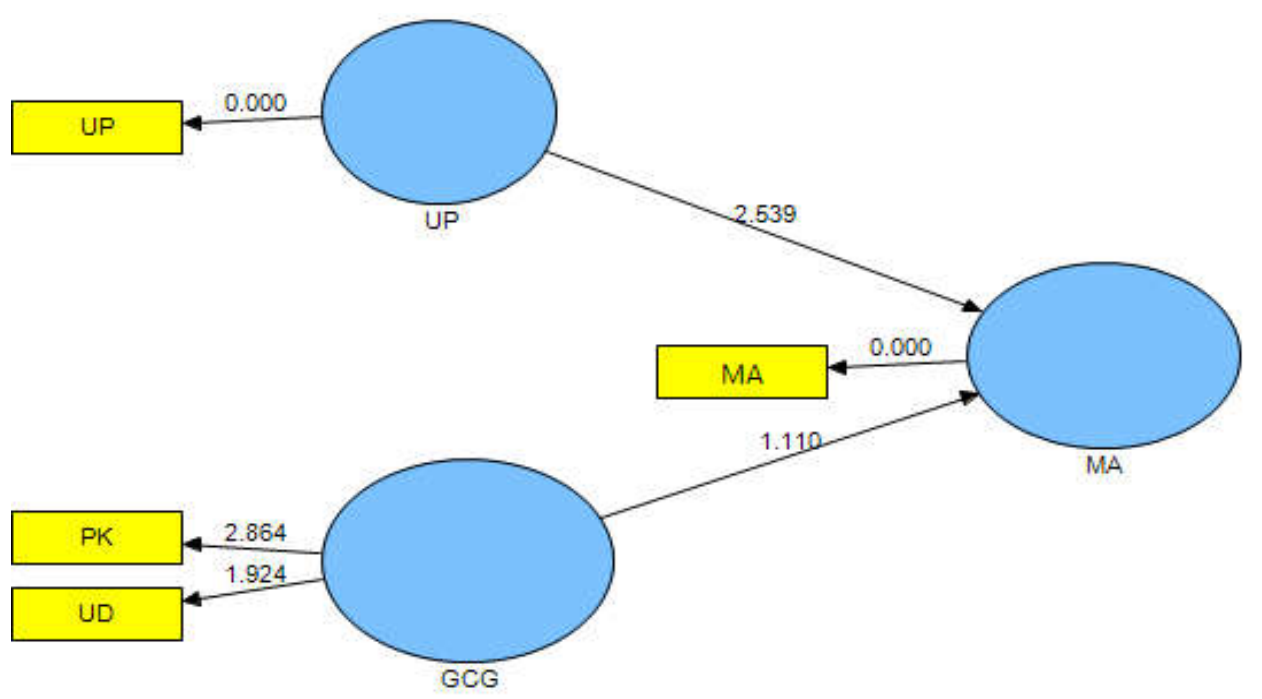

Figure 6 - Company Size and Good Corporate Governance (GCG) on Profit Management with moderation variables Audit Quality NON BigFour Source: Output Smart PLS 2.0

It can be seen from the figure 4.6 that after the firm size and good corporate governance variables in moderation with the quality of non-big four audit the size of the company has a value of 2,539 while the value of Good Corporate Governance (GCG) variable is 1,110 , which indicates that firm size affects earnings management in the period $2014-2015$.

Multigroup Hypothesis. The calculation of multigroup hypothesis is calculated to find out the final result $t$ statistic after firm size and good corporate governance to earnings management in moderation with audit quality ie big four or non big four. In order to conclude in detail whether firm size and good corporate governance to earnings management with audit quality as a moderation variable, then its calculation as follows:

Company Size:

$$
\begin{aligned}
& \text { UP } \\
& B 1=-0.110626 \\
& \mathrm{~B} 2=-0.326 \\
& \mathrm{~m}=63 \\
& \mathrm{t} \text {-value }(\mathrm{BIG} 4)=1.241516 \\
& \mathrm{t}-\text { Value }(\text { non BIG 4)= } 2.539416 \\
& \text { SE 1 }=0.079295 \\
& \text { SE } 2=0.1382 \\
& \mathrm{n}=199 \\
& t=\frac{\text { Path }_{\text {sample }_{1}}-\text { Path }_{\text {sample }_{2}}}{\left[\sqrt{\frac{(m-1)^{2}}{(m+n-2)} * S \cdot E 1^{2}+\frac{(n-1)^{2}}{(m+n-2)} * S \cdot E 2^{2}}\right] *\left[\sqrt{\frac{1}{m}+\frac{1}{n}}\right]} \\
& t=\frac{-0.110626-(-0.326)}{\left[\sqrt{\frac{(63-1)^{2}}{(63+199-2)} * 0.079295^{2}+\frac{(199-1)^{2}}{(63+199-2)} * 0.1382^{2}}\right] *\left[\sqrt{\frac{1}{63}+\frac{1}{199}}\right]}
\end{aligned}
$$

Good Corporate Governance:

GCG

$B 1=2.1891$

$\mathrm{B} 2=0.0972$

$\mathrm{m}=63$

$$
\begin{gathered}
\text { SE } 1=0.090121 \\
\text { SE } 2=0.100604 \\
n=199
\end{gathered}
$$




$$
\begin{gathered}
t=\frac{\text { Path }_{\text {sample }_{1}}-\text { Path }_{\text {sample }_{2}}}{\left[\sqrt{\frac{(m-1)^{2}}{(m+n-2)} * S . E 1^{2}+\frac{(n-1)^{2}}{(m+n-2)} * S . E 2^{2}}\right] *\left[\sqrt{\frac{1}{m}+\frac{1}{n}}\right]} \\
t=\frac{2.1891-0.0972}{\left[\sqrt{\frac{(63-1)^{2}}{(63+199-2)} * 0.090121^{2}+\frac{(199-1)^{2}}{(63+199-2)} * 0.100604^{2}}\right] *\left[\sqrt{\frac{1}{63}+\frac{1}{199}}\right]}
\end{gathered}
$$

\begin{tabular}{|c|c|c|}
\hline The Hypothesis in Proposed & Hypothesis Results & Conclusion \\
\hline $\begin{array}{l}\text { H1: Company size has a positive effect on earnings } \\
\text { management practices }\end{array}$ & 1.704 & $\begin{array}{c}\text { Not significantly positive } \\
\text { because below t-table } 1.96 \text {. }\end{array}$ \\
\hline $\begin{array}{l}\text { H2: Good Corporate Governance (GCG) negatively } \\
\text { affects earnings management practices. }\end{array}$ & 3.138 & $\begin{array}{c}\text { Significantly positive due to the } \\
\text { above t-table } 1.96 \text {. }\end{array}$ \\
\hline $\begin{array}{l}\text { H3: Audit quality is able to moderate the effect of firm } \\
\text { size on earnings management }\end{array}$ & 0.862 & $\begin{array}{c}\text { Not significantly positive due to } \\
\text { below t-table } 1.96 \text {. }\end{array}$ \\
\hline $\begin{array}{l}\text { H4: Audit quality is able to moderate the influence of } \\
\text { Good Corporate Governance (GCG) on earnings } \\
\text { management }\end{array}$ & 0.656 & $\begin{array}{l}\text { Not significantly positive } \\
\text { because below t-table } 1.96 \text {. }\end{array}$ \\
\hline
\end{tabular}

Table 8 - T-test Result

Source: Output Smart PLS 2.0

Model Evaluation. The structural model is assessed by looking at the R-Squares value for each endogenous latent variable as the predictor force of the structural model. The results of R-Squares using Smart PLS can be seen in the table below:

Table 9 - R Square

\begin{tabular}{|c|c|c|c|}
\hline \multirow{2}{*}{-} & Before Moderating & KAP BIG 4 & KAP NON BIG 4 \\
\cline { 2 - 4 } & R Square & R Square & R Square \\
\hline GCG & & & 0.13816 \\
\hline MA & 0.06481 & 0.04678 & \\
\hline UP & & & \\
\hline
\end{tabular}

Source: Output Smart PLS 2.0

Based on the test results in table 4.4 then obtained $\mathrm{R}$ amounted to 0.064813 before moderation and after moderated 0.04678 at big four and 0.13816 KAP with non four big audit quality. $R$ shows the correlation between two variables to earnings management. $R$ value ranges from 0 to 1 . If the value is close to 1 , then the relationship gets closer. Conversely, if close to 0 , then the relationship is weak. This shows under the weak relationship. This shows that there is a weak relationship between company size and good corporate governance to earnings management with audit quality as a moderating variable.

\section{DISCUSSION OF RESULTS}

The size of the Company Affects Profit Management. The results of this study indicate that firm size does not positively affect earnings management with the value of $t$-count 1,704 below 1.96, thus $\mathrm{H} 1$ is not accepted.

The reasons that support the results of this study is that each company can make earnings management, because by applying earnings management companies can maximize profits so it can be concluded that to apply earnings management does not have to be based on the size perusahaan. Hasil research is in line with research AT Marjani (2013) Stated that firm size has no positive effect on earnings management.

Good Corporate Governance (GCG) Affects against Profit Management. The results of this study indicate that Good Corporate Governance (GCG) has a significant positive effect on earnings management with t count is 3.138 above 1.96, thus $\mathrm{H} 2$ accepted. 
This research is supported by previous research that this is because many number of board of commissioner tend to do earnings management (Kodriyah, 2015). From this result, it can be concluded that the more internal board of commissioners know the level of profitability of a company for the benefit of a group (commissioner) coupled with the lack of efficient supervisory power because of the many interventions even in the eyes of the public as the level of supervision of the commissioner is very effective but the efficiency and effectiveness must Go hand in hand for better corporate.

The Effect of Audit Quality in Moderating The Influence Of Company Size To Profit Management. These results indicate that the audit quality used in the big four or non big four can not demodulate the effect of the size of manufacturing firms in Indonesia to the practice of earnings management with $\mathrm{t}$ counts of 0.862 below 1.96 , thus $\mathrm{H} 3$ is not accepted.

As for the reasons that support the outcome is the litigation risk against big four KAP in Indonesia is quite low. A legal environment that is still not good with the lack of lawsuits that could damage the reputation of big four KAP caused the low litigation risk. Large KAPs become the impetus for earnings management in client companies.

Supported by Yasar Alplasan (2013) research that there is no difference in quality of KAP big four audit or KAP non big four in preventing earnings management practice.

The Effect of Audit Quality in Moderating the Influence of Good Corporate Governance (GCG) to Profit Management. These results indicate that the audit quality used by the big four or non big four can not moderate the influence of good corporate governance of manufacturing in Indonesia to the practice of earnings management with $t$ count is 0.656 below 1.96, thus $\mathrm{H} 4$ is not acceptable.

As for the reasons that support the results are manufacturing companies in this study did not pay attention to the big four or non big four KAP will audit their companies in detecting earnings management, but the main thing for the company is how the KAP can produce quality audit reports. Supported by research Lestiyani Fita (2014) that the quality of audits generated not only measured by big four or non big four KAP but from audit reports and auditor independence.

\section{CONCLUSION}

Based on the results of the test analysis then obtained the following conclusions: the size of the firm has no significant positive effect on earnings management; Good Corporate Governance (GCG) has a significant positive effect on earnings management; Quality Audit can not moderate the effect of firm size on earnings management; Quality of audit can not moderate Good Corporate Governance (GCG) to earnings management.

In this research finding can give implication that is:

Contributing company size and good corporate governance to earnings management with audit quality as a moderating variable and providing additional knowledge and information related to firm size and good corporate governance to earnings management with audit quality as moderation variable;

Provide insight and insight and add reference to auditing. Especially about company size and good corporate governance to earnings management with audit quality as moderation variable;

Become an understanding of the quality of information as a reference by the parties investors, shareholders, creditors in decision-making.

The researcher gives recommendation for limitation from this research is the following:

Expand the object of research so that the results obtained can reflect the manufacturing company in general and provide more useful conclusions;

Adding other variables that are expected to affect earnings management, such as ROA, share value and audit committee. Thus it can be found more variances of variables affecting earnings management;

Extend the observation period so that more amount of data is used. It is expected that the results will be more accurate. 


\section{REFERENCES}

1. Abdillah Willy, Jogiyanto. 2015. Partial Least Square.Yogyakarta. Andi.

2. Agustia Dian. 2013. Pengaruh Faktor Good Corporate Governance, Free Cash Flow dan Leverage terhadap Manajemen Laba. Surabaya. Jurnal Akuntansi dan Keuangan Vol 15 No 1.

3. Asyraf Afthanorhan, Nazim, A., \& Ahmad, S. 2014. A Parametric Approach to Partial Least Square Structural Equation Modelling of Multigroup Analysis (PLS-MGA). International of Economics, Commerce and Management United Kingdom, II (10), 1-15.

4. AT, M., \& Puspitosarie, E. 2013. Jurnal Manajemen dan Akuntansi Volume 2.

5. Anggana, G. R., \& Prastiwi, A. 2013. Analisis Pengaruh Corporate Governance of (Studi pada Perusahaan Manufaktur di Indonesia). Diponegoro Jurnal of Accounting, 2, 1-12.

6. Anugerah Rita 2014. Peranan Good Corporate Governance Dan Fraud.

7. Alvin. A. Arens, Randal J. Elder, Mark S. Beasley, Amir Abadi Jusuf, (2011), Audit dan Jasa Assurance: Pendekatan Terpadu (Adaptasi Indonesia), Jakarta: Penerbit Salemba Empat.

8. Barus, A. C., \& Setiawati, K. 2015. Pengaruh Asimetri Informasi, Mekanisme Corporate Governance, dan Beban Pajak Tangguhan Terhadap Manajemen Laba, 5, 10.

9. Bismark, R., Pasaribu, F., Kowanda, D., Firdaus, M., \& Ummah, R. N. 2015. Mekanisme Good Corporate Governance, Ukuran Perusahaan, Struktur Kepemilikan Manajerial Dan Perbankan Di Bursa Efek Indonesia, 1-22.

10. Effendi, S. 2013. Pengaruh Corporate Governance Dan Kualitas Audit Terhadap Manajemen Laba, 2, 1-14.

11. Febriyanti Dewi, Made, N., \& Metha, Made, I. 2014. Pengaruh Masa Perikatan Audit, Rotasi KAP, Ukuran Perusahaan Klien, dan Ukuran KAP Pada Kualitas Audit. E- Jurnal Akuntansi Universitas Udayana, 2, 503-518.

12. Ghozali. (2010). Aplikasi Analisis Multivariate dengan Program SPSS. Cetakan V. Semarang: Badan Penerbit Universitas Diponegoro.

13. Hery. (2016). Auditing dan Asuransi. Jakarta. Grasindo

14. Kristiani, Emi, K., Sulindawati, Erni, Gede, Luh, N., \& Herawati, Trisna, N. 2014. Pengaruh Mekanisme Corporate Governance dan Ukuran Perusahaan, 1(1).

15. Mustika, G., Sari, Nelly, R., \& L, Azhar, A. (2014). Pengaruh Pengungkapan Corporate Social Responsibility Terhadap Manajemen Laba, 3(9), 1-16.

16. Kodriyah. 2015. Pengaruh Kepemilikan Institusional, Ukuran Perusahaan,Leverage dan Good Corporate Governance Terhadap Manajemen Laba((Studi Empiris Perusahaan Manufaktur yang terdaftar di BEI 2009-2012). Jurnal Akuntansi Vol 2 No 1 Juli 2015. Jurnal Akuntansi Vol 2 No 1 Juli 2015.

17. Sunandar, Farida Ida, Alfin Muhammad. 2014. Pengaruh Kualitas Audit dan Ukuran Komite Audit terhadap Manajemen Laba. Surabaya. Jurnal Bisnis dan Manajemen Vol 2, No.2.

18. Tunggal Widjaja Amin. 2016. Teknik-Teknik Pencegahan Kecurangan Karyawan dan Manajer Haraido

19. Wind, Ajeng. 2014. Forensic Accounting. Jakarta Timur: Dunia Cerdas.

20. Wiryadi, A., \& Sebrina, N. 2013. Pengaruh Asimetri Informasi, Kualitas Audit, dan Struktur Kepemilikan terhadap Manajemen laba, 1(2), 155-180.

21. Www.idx.co.id, di akses maret 2016

22. Yasar, A. (2013). Big Four Auditors' Audit Quality and Earnings Management: Evidence from Turkish Stock Market Department of Accounting and Finance, 4(17), 153-163. 